\title{
Successful Module Hot Spot Testing of 120 ppma Carbon Contaminated Silicon Feedstock
}

\author{
Kees Broek, Nico Dekker, Gianluca Coletti \\ Energy Research centre of the Netherlands ECN, Petten, Netherlands
}

\begin{abstract}
Several options for solar grade silicon feedstock have been investigated over the years to bring down the costs of silicon wafers. Generally the resulting silicon contains higher levels of impurities, the level depending on the refining processes. In this work wafers from a p-type mc-Si ingot made with feedstock contaminated with 120 ppma of carbon have been processed firstly into solar cells and secondly into 60-cell solar modules. The focus here is to study the module reliability. It was demonstrated that a hot spot endurance test could be passed without any problems.
\end{abstract}

Index Term - carbon, feedstock, hot spot testing, multi crystalline silicon, photovoltaic cells, solar grade silicon

\section{INTRODUCTION}

Several options for solar grade silicon feedstock have been investigated over the years to bring down the costs of silicon wafers. A p-type mc-Si ingot grown with 120 ppma carbon containing feedstock was investigated by ECN to study the impact of carbon on solar cell performance [1].

Carbon as a dissolved impurity in silicon causes few problems, because it occupies a substitutional place in the lattice and is electrically neutral [2]. The solubility of carbon is 9 ppma at the melting point. Above this level, carbon precipitates as silicon carbides, which are good conductors. As they grow preferentially along the solidification front, they tend to contact two polarities of a solar cell, leading to severe shunting [3].

The studied 120 ppma carbon ingot had been processed by controlled carbon precipitation during crystallisation. This resulted in wafers containing around 9 ppma carbon and no evidence of silicon carbide precipitates was found. Solar cells were made of high carbon contaminated feedstock in the ECN lab and their performance was comparable to cells from a reference ingot without carbon contamination. Moreover, EL images showed that the current was dissipated fairly homogeneously over the entire cell, avoiding small hot spot formation [1] even at $-16 \mathrm{~V}$. In [1] it was demonstrated that comparable reverse current, shunts, and efficiencies can be reached for carbon contaminated and reference cells.

The goal of the current research is on one hand to show that good cells from high carbon contaminated feedstock can be manufactured in an industrial environment and on the other hand that it is possible to make good solar modules that will pass a hot spot endurance test.
The multicrystalline p-type wafers came from two blocks out of one ingot, one from the centre and the other one from a corner. Three groups of wafers were taken from different positions in the centre block: top, middle and bottom. Two groups of wafers came from the corner block: top and bottom position. All groups contained 100 wafers each.

The cells were manufactured in a fully industrial setting with standard p-type processing techniques (state of the art 2013). The average cell efficiency was $17.5 \%$, see Table I.

TABLE I

MEdian Cell Parameters Per GROUP

\begin{tabular}{|l|c|c|c|c|c|}
\hline $\begin{array}{l}\text { Group } \\
\text { (Block/Position) }\end{array}$ & $\begin{array}{c}\mathrm{I}_{\mathrm{sc}} \\
(\mathrm{A})\end{array}$ & $\begin{array}{c}\mathrm{V}_{\text {oc }} \\
(\mathrm{mV})\end{array}$ & $\begin{array}{c}\mathrm{FF} \\
(\%)\end{array}$ & $\begin{array}{c}\eta \\
(\%)\end{array}$ & $\begin{array}{c}\mathrm{I}_{\text {rev }} \\
(\mathrm{A})\end{array}$ \\
\hline 1 Centre/Bottom & 8.78 & 634 & 77.6 & 17.7 & 0.05 \\
\hline 2 Centre/Middle & 8.73 & 630 & 77.3 & 17.4 & 0.07 \\
\hline 3 Centre/Top & 8.65 & 623 & 77.6 & 17.2 & 0.10 \\
\hline 4 Corner/ Bottom & 8.74 & 630 & 78.1 & 17.7 & 0.06 \\
\hline 5 Corner/Top & 8.67 & 627 & 78.0 & 17.4 & 0.09 \\
\hline
\end{tabular}

Note: Cells measured at STC at the manufacturer

The cell efficiency was highest at the bottom of the blocks which is conform to the expectation that metal impurity contaminations segregate to the top of the block during solidification [4].

The complete batch of cells was sorted on efficiency in order to minimise mismatch in the modules. Seven 60-cell modules were built at an industrial module manufacturer (state of the art 2013). Stringing started with the highest efficiency cells but the module lay-up started with the strings lastly made. Thus module \#1 gave the lowest power output and module \#7 the highest with a difference of $3 \%$, see Table II.

TABLE II

PARAMETERS OF HIGHEST AND LOWEST POWER MODULES

\begin{tabular}{|l|c|c|c|c|c|}
\hline Module & $\begin{array}{c}\mathrm{P}_{\mathrm{mp}} \\
(\mathrm{W})\end{array}$ & $\begin{array}{c}\mathrm{I}_{\mathrm{sc}} \\
(\mathrm{A})\end{array}$ & $\begin{array}{c}\mathrm{V}_{\mathrm{oc}} \\
(\mathrm{V})\end{array}$ & $\begin{array}{c}\mathrm{FF} \\
(\%)\end{array}$ & $\begin{array}{c}\eta \\
(\%)\end{array}$ \\
\hline$\# 1-\mathrm{B} 247$ & 246.6 & 8.93 & 37.38 & 73.89 & 16.92 \\
\hline$\# 7-\mathrm{B} 253$ & 254.9 & 9.06 & 38.06 & 73.96 & 17.48 \\
\hline
\end{tabular}

Note: Modules measured at STC at ECN; $\eta$ is the encapsulated cell efficiency.

\section{Cell ANd Module Manufacturing}




\section{HOT SPOT ENDURANCE TEST}

The hot spot endurance test was chosen as main instrument to test the durability of cells on the basis of high carbon feedstock. The purpose of the test is to determine the ability of a module to withstand hot-spot heating effects, e.g. solder melting or deterioration of the encapsulation. This effect could be provoked by cracked or mismatched cells, shunts, interconnection failures and partial shadowing or soiling.

The method described in the IEC type approval test [5] is debatable as it is incorrect for modules with bypass diodes. Therefore, the external test institute did not use the height of $I_{s c}$ in zone A (Fig. 1) for selection of one shaded cell, but the current in zone B when the bypass diode turns on. This is common practise. Moreover, four cells instead of one were selected to be more conservative in the study despite the standard focus on a single cell. Three cells with the lowest and one cell with the highest shunt resistance $\mathrm{R}_{\text {shunt }}$ were selected. In the next step, one by one, the selected cells were partially covered under illumination, while an IR-camera measured the cell temperature.

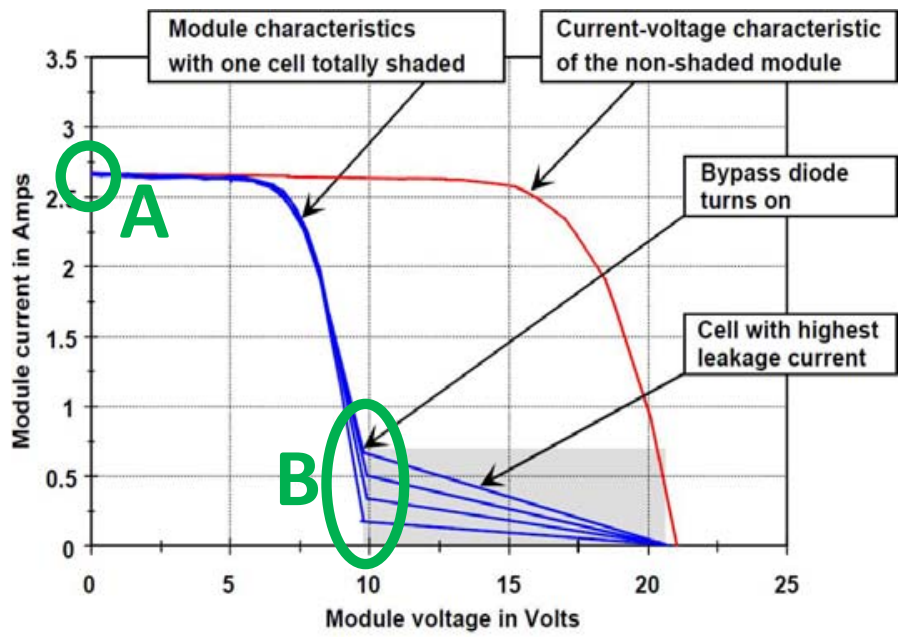

Fig. 1: Module IV-characteristics of a module with one cell totally shaded and one curve in a non-shaded situation [6]. The current hot spot test focusses on area $A$, whereas the test institute focussed on area $B$.

The partial coverage, resulting in the highest cell temperature, was applied in the second phase of the hot spot test. Then the module was illuminated at $1000 \mathrm{~W} / \mathrm{m}^{2}$ while a selected cell was covered in a worst case condition for one hour at a test temperature range of $40-60^{\circ} \mathrm{C}$. This was repeated for all the other selected cells.

The improved and applied method for the hot spot endurance test is believed to become part of a new IEC standard to be approved in the near future.

\section{RELIABILITY TESTING}

Module \#7 was selected for testing at an external test institute. This module contained 47 cells from group 1, 1 cell from group 2 and 12 cells from group 4 (See Table I). It was subjected to the following test sequence:

1) Initial IV-test under STC (IEC test 10.2)

2) Preconditioning (10.1)

3) IV-test under STC (10.2)

4) Insulation test (10.3)

5) Hot-spot endurance test (10.9 modified)

6) Final IV-test under STC (10.2)

7) Final Insulation test (10.3)

8) Wet Leakage test (10.15)

This module and a control (\#6) were characterised by IV at ECN before and after the test sequence.

\section{A. Results hot spot endurance test}

In the first phase of the test 60 IV-curves were measured while one cell was fully shaded. Figure 2 shows four of those curves plus the curve of the unshaded module.

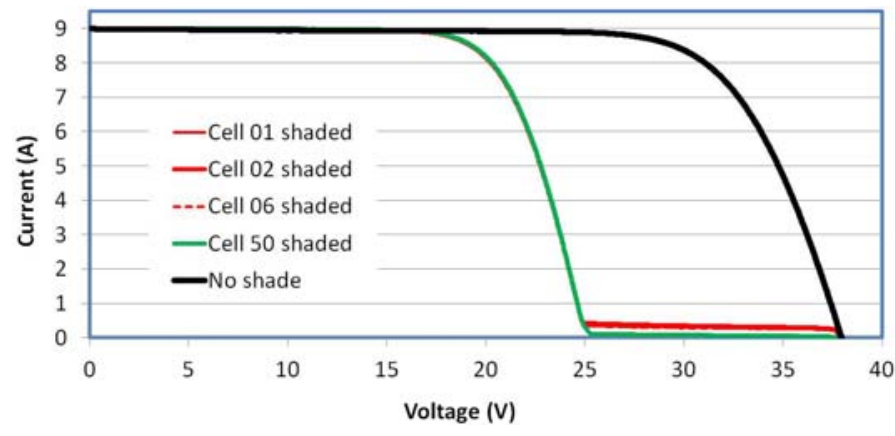

Fig. 2: Unshaded IV-curve of module \#7 and four curves with fully shaded cells.

Three cells (1, 2 and 6) with the lowest shunt resistance (i.e. the highest $\mathrm{I}_{\text {rev }}$ ) and one cell with the highest shunt resistance (50) were selected for illumination in phase 2 of the hot spot test.

TABLE III

Selected Cells in the Hot Spot Test

\begin{tabular}{|c|c|c|c|}
\hline Cell & $\mathrm{I}_{\text {rev }}(\mathrm{A})$ & Shade & $\mathrm{T}_{\max }\left({ }^{\circ} \mathrm{C}\right)$ \\
\hline 1 & 0.07 & $10 \%$ & 100 \\
\hline 2 & 0.05 & $10 \%$ & 102 \\
\hline 6 & 0.06 & $10 \%$ & 110 \\
\hline 50 & 0.04 & $10 \%$ & 98 \\
\hline
\end{tabular}

The $\mathrm{I}_{\text {rev }}$ values (Table III) measured by the cell manufacturer are all low. The maximum heat effect of all selected cells was reached at a shading level of $10 \%$. The last column shows the 
maximum cell temperature in the next part of the test. The selected cells are shown in Fig. 3, next to an EL-picture of module \#7. The dark spots in the cells are wafer dependent.

\begin{tabular}{|c|c|c|c|c|c|}
\hline 1 & 2 & 3 & 4 & 5 & 6 \\
\hline 7 & 8 & 9 & 10 & 11 & 12 \\
\hline 13 & 14 & 15 & 16 & 17 & 18 \\
\hline 19 & 20 & 21 & 22 & 23 & 24 \\
\hline 25 & 26 & 27 & 28 & 29 & 30 \\
\hline 31 & 32 & 33 & 34 & 35 & 36 \\
\hline 37 & 38 & 39 & 40 & 41 & 42 \\
\hline 43 & 44 & 45 & 46 & 47 & 48 \\
\hline 49 & 50 & 51 & 52 & 53 & 54 \\
\hline 55 & 56 & 57 & 58 & 59 & 60 \\
\hline
\end{tabular}

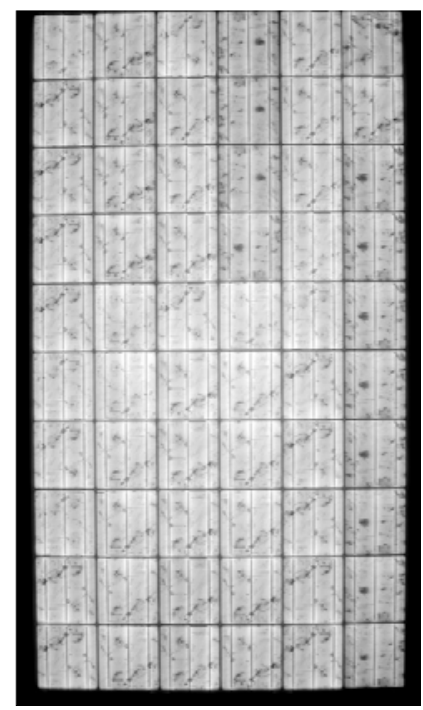

Fig. 3: The selected cells (red $=$ low $R_{\text {shunt }} ;$ green $=$ high $R_{\text {shunt }}$ ) of module \#7 at the left and the EL image at the right.

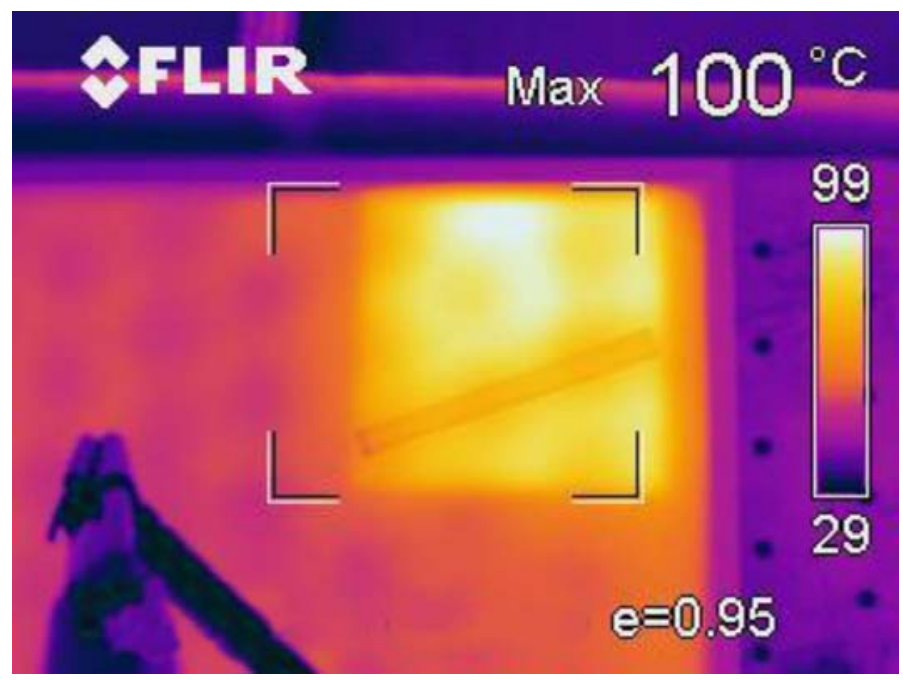

Fig. 4: IR-picture of cell 1 while it was $10 \%$ shaded during the one hour illumination of the module.

In phase 2 of the test each selected cell was covered for $10 \%$ while the other cells remained uncovered and the module was exposed to a sun simulator at $1000 \mathrm{~W} / \mathrm{m}^{2}$ during one hour. The maximum temperature measured was $110^{\circ} \mathrm{C}$.

The IEC61215 criteria for passing the hot spot endurance test were all met:

- No evidence of major visual defects;

- No power degradation exceeding 5\%;
- Sufficient insulation resistance.

\section{B. Results of additional tests}

In preconditioning the module was exposed to simulated sunlight to an irradiation level of $5 \mathrm{kWh} / \mathrm{m}^{2}$ while opencircuited. The module passed the preconditioning without any remarks.

In the isolation test is determined if the module is wellinsulated between current-carrying parts and the frame of the outside world. First a $3 \mathrm{kV}$ voltage was applied and afterwards the maximum system voltage $(1 \mathrm{kV})$ was applied for two minutes. The isolation value was around $135.10^{3} \mathrm{M} \Omega$ at both tests, which is far above the criterion for a 60 -cells module (25 M $\Omega$ ).

In the wet leakage current test the insulation of the module under wet operation conditions is evaluated. The maximum system voltage $(1 \mathrm{kV})$ was applied for two minutes followed by the measurement of the insulation resistance. The resistance found was $522 \mathrm{M} \Omega$ which was above the criterion for a 60 -cells module ( $25 \mathrm{M} \Omega$ ).

The test module (\#7) and a control (\#6) were characterized in IV before and after the test sequence in the Pasan flash tester at ECN. The small changes in parameters were comparable as shown in Table IV. This confirms the conclusion that module \#7 had successfully passed all tests applied, including the modified IEC hot spot endurance test.

TABLE IV

Changes IN IV in Module \#7 Before AND After Testing

\begin{tabular}{|l|c|c|c|c|}
\hline Module & $\mathrm{P}(\mathrm{W})$ & Isc (A) & Voc (V) & FF (\%) \\
\hline \#7 Tested & $-0.5 \%$ & $0.3 \%$ & $-0.2 \%$ & $-0.5 \%$ \\
\hline \#6 Control & $-0.5 \%$ & $0.0 \%$ & $-0.1 \%$ & $-0.5 \%$ \\
\hline
\end{tabular}

\section{CONCLUSION}

Solar cells based on 120 ppma carbon-contaminated feedstock were made in an industrial process with an average efficiency of $17.4 \%$. Seven solar modules were built with an encapsulated cell efficiency ranging from 16.9 to $17.5 \%$.

A module with high carbon wafers had successfully passed a hot spot endurance test, including preconditioning, an insulation test and a wet leakage current test showing no performance degradation.

\section{REFERENCES}

[1] P. Manshanden and G. Coletti, "Solar cells from 120 ppma carbon-contaminated feedstock without significantly higher

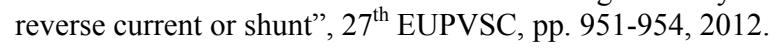

[2] R.C. Newman, "Defects in Silicon", Rep. Prog. Phys., Vol. 45, p. 1163, 1982.

[3] J. Bauer, O. Breitenstein, and J.P. Rakotoniaina, $21^{\text {st }}$ EUPVSC, p. $1115,2006$. 
[4] G. Coletti, et all, "Impact of Metal Contamination in Silicon Solar Cells”, Adv. Funct. Mater., 21: 879-890, 2011.
[5] IEC 61215, “Crystalline silicon terrestrial (PV) photovoltaic modules - Design qualification and type approval", $2^{\text {nd }}$ edition, 2005.

[6] J. Wohlgemuth and W. Herrmann, "Hot spot tests for crystalline silicon modules”, PVSC 31, pp. 1062-1063, 2005. 